\title{
From Adaptation to Ruralization: A historical Analysis of Curriculum Policy Implementation in Cameroon Schools from the Colonial to Post Colonial Period
}

\author{
Yaro Loveline $(\mathrm{PhD}) *$ \\ Curriculum studies and Teaching, Faculty of Education, University of Buea, Cameroon
}

*Corresponding Author: Yaro Loveline, Curriculum studies and Teaching, Faculty of Education, University of Buea, Cameroon

\begin{abstract}
The issue of relevance of schools Curriculum in Cameroon has always been in debate since the introduction of formal education in Cameroon. While Cameroon education has been influenced by Western Education, it is argued that between 1884 and 1961, Cameroon was administered by different colonial masters who aimed at controlling the life of the native Cameroonian politically, economically, socially and culturally. As far as education was concerned, each colonial administration developed a philosophy that was based on their individual interests. MacOjong (2008) holds that, apart from promoting their culture and civilization, the goals of colonial masters in Cameroon were mainly for economic gains. They therefore introduced formal education as a tool to produce rudimentary manpower required for economic exploitation. During this period, Cameroonians were mainly at the receiving end. They had little or no input in matters of education policy. Consequently, education policy did not reflect the real wishes and needs of Cameroonians. The practice of ignoring or not requiring the contribution of Cameroonians in policy matters was later decried by Cameroonian elite and nationalists who had succeeded in acquiring an appreciable level of the western type of education. These nationalists and elite championed the cause of independence and subsequently became political leaders of Cameroon following the achievement of independence. The postcolonial period was a turning point in Cameroon's education system. Because of this, educational policy was expected to undergo a radical change. A shift was expected, from the colonial philosophy which considered education in Africa as a vehicle of colonial interests, to the African perspective of meeting the needs of national independence and development in all aspects of national life. This was expected to be the point of departure for formulating a new road map for educational development in Cameroon. The issue of curriculum policy has been a subject of debate at the national level. Shu (1982) pointed out that among the problems of education in Cameroon is the lack of a formal criterion for the formulation and implementation of education policy in Cameroon. This situation according to him, explains why they had been no comprehensive national education policy which can stay while individual politicians and civil servants come and go. According to this argument, education policies change as the ministers change, thereby providing no opportunity for a complete implementation of any policy. The study aims at providing a historical analysis of the extent to which the policy of ruralisation has influenced education efforts in Cameroon from the colonial period to present
\end{abstract}

Keywords: Adaptation to Ruralization, historical Analysis, Curriculum Policy Implementation, Cameroon Schools and Colonial to Post Colonial Period.

\section{INTRODUCTION}

From the period of 1914 when the Germans began to leave Cameroon to 1922 when Britain and France effectively took control of the territory, there was barely an educational system in the British administered Cameroon. What passed for education were classes operated by native Cameroonian catechists. Education in the British territory started off less smoothly than in the French territory. Education was left in the hands of the church. It was only by 1922 that the British directly got involved in education matters in Cameroon by organizing an official education system with direct control by the mandatory power.

Being administered as part of British territory in Nigeria, the educational policies instituted in Nigeria were imposed in the Cameroons. Britain assumed responsibility for the administration of the Southern Cameroons as 'a sacred trust of civilization' (Aka, 2002. P. 58). Education was therefore seen as a 
From Adaptation to Ruralization: A historical Analysis of Curriculum Policy Implementation in Cameroon Schools from the Colonial to Post Colonial Period

vital instrument for realizing that responsibility of securing the 'liberty, material and opportunity for development of the native inhabitants' (Aka, 2002. P. 58). It was therefore asserted that:

There is not only a moral obligation resting on governments in Africa to enable Africans to develop their capacities to the full and to open as widely as possible the doors of knowledge to those who can profit by an advanced education, but the general progress of the people depends on... highly trained African leaders of all walks of life (Aka, 2002. P. 59).

According to Aka (2002), after the First World War, it was suggested during the Paris Peace Settlement that the United States of America (US) be given mandate to administer the Cameroons, but this suggestion did not materialize because the US did not show any interest in colonial acquisition, but rather adopted the policy of Isolation and did not become a member of the League of Nations. Although the US isolated itself from the rest of the world during this period, the development of education in the British Tropical African Dependencies, including Southern Cameroons was dominated by its ideas. Aka (2002) termed this 'cultural imperialism' (p.56). The American cultural influence dominated the development of education in the Southern Cameroons through the ideas and policy of Adaptation of Education propounded by the Phelps Stokes Commission. The Adaptation of Education policy during the British rule is synonymous to Cameroon's present curriculum policy of Ruralization.

The American Presbyterian Board of Foreign Mission (BFM) which was set up in Cameroon in 1885 during the period of German Administration continued to provide education in the territory. They became increasingly concerned about the type of education that was being provided in Africa and felt that the African societies were not deriving full benefits from whatever was being invested, mainly because the system was not related to the economic and social needs of the people. Consequently, the BFM decided that it would no longer provide more of its resources to the educational development in Africa without first carrying out an elaborate study of the conditions and needs of the people. The Phelps Stokes Commission thus provided the adequate personnel and financial resources for such a study to be carried out and published.

The fund which was established by Miss Carline Phelps Stokes in 1911 was meant to support the education of 'negroes both in Africa and the United States' (Aka, 2002. P. 57). When the PhelpsStokes Commission for education was created in 1919, Southern Cameroon which was administered as part of Nigeria was one of the African countries that benefited from the educational opportunity offered by the Commission. The Commission soon established that Education was dysfunctional mainly because adequate information on the cultural background and needs of African societies had not yet been available. They felt that an elaborate study on the social and economic conditions in Africa be undertaken and that there should be adequate cooperation between experts representing American and European missionary bodies in order to make any further investments yield the desired results (Aka, 2002. P. 58).

The Phelps Stokes Commission did not see the development of education as an end in itself but as an investment which should satisfy the immediate and long term interests and aspirations of the individual and the society. For these to be realized, education was thus expected to enable a child to have sufficient knowledge of his or her environment. Education was to be pragmatic, and equip the child with ideas, skills and technology practically relevant and suitable for the development of his or her society. While stating that a system of education which is relevant to the needs of one society cannot necessarily meet the needs of another society unless the two societies are identical in their standards and patterns of economic and social developments, the Commission argued that 'the wholesale transfer of the educational conventions of Europe and America to the peoples of Africa has not been an act of wisdom (Aka, 2002. P. 58). They advocated for education that should be adapted to the needs of the individual and the community.

The British, following the recommendation of the Phelps-Stokes Commission, adopted the adaptation policy. The awareness of ruralization in Cameroon started with the Phelps-Stokes Commission report of 1922 entitled 'Education in Africa, advocating for the adaptation of school practices to the needs of the individual and the community. 
From Adaptation to Ruralization: A historical Analysis of Curriculum Policy Implementation in Cameroon Schools from the Colonial to Post Colonial Period

In an investigation carried out by the Phelps-Stokes commission, on the educational needs in Africa, results were made and reported in a document entitled "Education in Africa, 1922". The report revealed the following three critical issues:

- The need to adapt education to the environment

- The need for mass education in view of its integration in the development process

- The need to train an indigenous teacher's corps, conscious of their responsibilities and duties (Fonkeng, 2006).

The Commission suggested curriculum which should emphasize the development of character, health, agriculture and industrial skills, the improvement of family life and the encouragement of healthy recreation. As a means of achieving these, the report spelt out six major strategies for programme adaptation. Tambo in (Kaba and Rayapen, 1990) lists them as follows:

- School subjects (reading, arithmetic, hygiene, etc.) were to be made to contribute to an increased respect for an interest in the rural environment of the school.

- The organization of activities within the school room should blend intimately with the life of the groups from whom the pupils come.

- The organization of the 'movable' school based on the itinerant teachers who will go out from central school to the distant villages and teach by doing the simple elements of life needed by the men, women and children.

- Farm-demonstrations to introduce innovations in farming methods in the locality.

- Home-demonstration to enlist the interest of the women and the girls in all that pertains to the economic and social welfare of the home and the community.

- Organization of farm-makers cubs for boys to encourage the growing of crops and the raising of livestock.

In an attempt to implement these strategies, the Jeanes school movement in Kenya took up the campaign to sensitize and encourage teachers to link the activities of their school to those of the village. This initiative pushed the colonial governments to issue policy statements recommending the creation of rural schools 'freed from the shackles of ambitious academic curricula; a school at the same time a farm, a workshop, a dispensary and a field of experiment' (Tambo, as cited in Kaba and Rayapen, 1990. P. 106).

The Phelps Stokes Commission also advocated for mass education which was important in preventing disintegration of the African societies under the influence of western civilization. It stressed that educational reform must be connected to the education of the young to the general advancement of the community. Therefore, the type of education to be offered to Cameroonians must be that which is rooted in the needs of the community because 'the school can only fulfil its function if it is part of a more general programme conceived in terms much wider than the work of the school' (Aka, 2002.p.60). Adult education was thus encouraged, since it was considered that the progress of a backward community will be greater and more rapid if the education of the adults is taken up concurrently with that of the young. The commission further argued that community education should develop an inseparable relationship between an individual and his society, in which the individual sees his own personal progress as meaningless unless it is accompanied by that of the whole society. Consequently, education should adapt to and reflect the socio-economic and political realities and aspirations of the community.

This worked for a while but later in the 1940's individuals started questioning the philosophical and strategic basis of the adaptation policy. They interpreted it as an attempt by the colonial authorities to provide the African child with an inferior type of education. Aka (2002) argued that though the adaptation philosophy leaned heavily on pragmatism and realism, the Phelps Stokes Commission carried the idea too far. He continued that the ideas that guided the development of community education were abused. The commission drew a distinction between urban and rural communities and accordingly recommended a two tract system of education, one for the urban areas meant for the rich of the society and the other for rural communities basically made up of the poor and the under privileged. Ball, in Ndille (2015) added that, vehement opposition also came from the rural folks who 
From Adaptation to Ruralization: A historical Analysis of Curriculum Policy Implementation in Cameroon Schools from the Colonial to Post Colonial Period

saw in the innovation, an attempt to condemn their children to a life of hardship from which only the school could save them as it had done for others; the elites.

From the colonial period, bookish education followed by academic secondary and higher education seemed to be what was desirable to most African people for the simple reason that it provided a ladder to an altogether different world of increased financial and enhanced social status. He added that:

Education meant reading books, writing and talking English and doing arithmetic.... At our homes we have done a lot of ploughing, planting, weeding and harvesting.... We knew how to do these things. What we knew was not education; education was what we did not know; that which would give our children a big government office in town (Ball, 1983. P. 253).

Tambo, in Kaba and Rayapen (1990) added that, the ruralized programmes of the colonial period were also criticized because they were often relegated to the primary schools level. Secondary schools were regarded as 'academic' institutions meant to prepare students for higher studies and immediate jobs and consequently ensuring a better life. This, therefore, meant that parents frowned on the school attempt at ruralization because it did not equip young people for service and life outside their community. Thus, the early adaptation of both the ruralized curriculum and pattern of the school organization was unaccepted by the rural population.

Adaptation of education was furthered resisted in Cameroon because the commission ignored the fact that the developmental needs of Cameroon were different from that of Nigeria, the educational policies dealing with the opening of schools, curriculum financing and the registration of teachers in Nigeria were extended to Cameroon without analyzing the specific needs of the Cameroonian population. The Nigerian code of 1926 was the major document that constituted the foundation of regulations that guided the educational development in British Cameroon. Education during the British administration in Cameroon witnessed some problems among which were Lack of an educational policy specifically conceived for Cameroon, failure to totally implement the adaptation policy, failure to promptly develop post-primary institution and teachers training colleges which resulted in the lack of qualified staff to take up the available job opportunities.

Gwanfogbe (2006) argued that the primary goal of colonial education in Cameroon was to prepare the youth for the demands of the society in its political, social and economic dimensions. These included literacy for Christian evangelization, colonial administrative assistantship and cultural assimilation. Furthermore, the schools set up by the Missionaries and colonial administrators became the highest systems of acculturation in Cameroon with religion, language and curriculum being the main instruments of such acculturation (UNESCO, 1985). Although there were visible differences in the educational goals of the various colonial administrations and missionaries during this period, indigenous education was pushed to the background as they all maintained that education must civilize the natives to act, think and behave like the white man (MacOjong, 2008).

As pointed out by Tambo (2003) the following categories of school emerged in British Cameroon;

- Government schools

- Native authority schools,

- Assisted Mission schools

- Unassisted Mission schools

- Post-primary schools

The period between the introduction of the Education code and the outbreak of the Second World War saw a remarkable growth in the educational system in terms of schools and enrolment. The first secondary school in British Cameroon, Sasse College, was opened during the British administration in Cameroon. Before 1931, primary school education took nine years to complete. From 1931, the duration was reduced to eight years reorganized into three stages: The infant stage, the elementary stage, and the middle class stage.

Throughout the trusteeship period, Cameroon was still administered as part of the Eastern Region of Nigeria and therefore educational legislation drawn up for Nigeria continued to be applied to the 
From Adaptation to Ruralization: A historical Analysis of Curriculum Policy Implementation in Cameroon Schools from the Colonial to Post Colonial Period

British Cameroons. For example, in 1952, the Education Ordinance was introduced so as to enable each of the newly created (Eastern, Western and Northern) regions to develop its educational policies and systems. The ordinance became an education law for the country. All schools whether public or private were to be subjected to inspection by the Regional Director or his representative and the Inspector General or his representative. From 1954, the territory became an autonomous region created by the Macpherson constitution. Consequently, Southern Cameroons was setup in Buea.

During the pre-colonial and colonial period in Cameroon, education remained under the whims and caprices of the colonial masters who dictated what education should be. However there was a gradual shift or evolution in the aims of education from the time of the early missionaries to the period of the German protectorate. Influenced by the Phelps Stokes Commission, the aims of education during the British mandate and trusteeship period radically changed (revolutionalized)from that which should satisfy the interests of the colonial masters, to that which 'must be deeply rooted in the needs of the community' ( Aka, 2002.p.60). However, this change of trend in the kind of education offered the natives was resisted because the natives saw that education that is adapted to their mentality, aptitudes, occupations and traditions had no economic benefits to them. Thus, they preferred the wholesale transfer of the educational conventions of Europe and America to the peoples of Africa to that preached by the Phelps Stokes Commission through its policy of Adaptation of Education.

In the colonial period, attempts were made to adapt education to the needs of the African communities. However, as the struggle for independence intensified, such attempts were rejected by African nationalists. They believed that adaptation was meant to provide an inferior education that would keep the Africans perpetually under the control of the colonial masters.

Nevertheless, on achievement of independence, there was a renewed interest in the adaptation policy. The first concerted effort to discuss adaptation in the post-colonial sense was made when Cameroon joined thirty-three other newly independent African countries in Addis-Ababa from May $16^{\text {th }}$ to $25^{\text {th }} 1961$ at a conference to provide a forum for these new African states to decide on their priority educational needs, to promote educational and social developments and to establish a first tentative short- term and long- term plan for educational development in the continent. The conference was designed to make an inventory of the needs of education in Africa, to take into account the many problems involved, and to recommend a programme to help those needs.

Addressing the conference in a paper titled "on the principal educational needs and plans for educational development in Cameroon", the representative from Cameroon identified among other things the problem of building and premises, teacher training, and printing of textbooks. There was equally an outcry for changes and reforms to be made on methods of teaching and school curricular. $\mathrm{He}$ also indicated in the report that a future prospect made by the government of Cameroon would be directed primarily to the extension of the existing types of education. This would be achieved through the implementation of the twenty- year plan for development that would develop secondary education and gradually establish higher education, and above all there would be a general development of school attendance and education. The extension of rural education suited to "bush life" and conducive to progress on both the technical and human level was also reiterated in the report (UNESCO/ EDAF/C/3).

The recommendations made at the end of the conference indicated that by 1980, primary school education must be universal, compulsory and free. That education at the secondary level should be provided to $30 \%$ of pupils who completed primary school. Recommendations made on the reform of the content of education held:

That the present content of education in Africa is not in line with either existing African conditions, the postulate of political independence, the dominant features of an essentially technological age, or the imperatives of balanced economic development involving rapid industrialization, but is based on a nonAfrican background, allowing no room for the African child's intelligence, powers of observation and creative imagination to develop freely and help him find his bearings in the world. African educational authorities should revise and reform the content of education in the areas of the curricula, textbooks, and methods, so as to take account of African environment, child development, cultural heritage and the demands of technological progress and economic development, especially industrialization; 
From Adaptation to Ruralization: A historical Analysis of Curriculum Policy Implementation in Cameroon Schools from the Colonial to Post Colonial Period

That the teaching of scientific and technical subjects be developed so as to ensure the training of highly qualified staff as speedily as possible (e. g. research workers, engineers, science teachers, economists, financial experts and statisticians); That curricula be reformed by allotting less time to the teaching of classics and ending the preferential treatment given to the teaching of non-African history and geography; That all aspects of humanistic education that could help in character formation be retained and while rooting itself in Africa's past, the educational content should not seal the student off from the rest of the world. The African States must make the necessary study of and changes in traditional attitudes so as to achieve, in their curricula, a synthesis of their own values and of universal values.

The delegates felt that "this direction will be an important factor in raising the productivity of the agricultural economy, in enriching the community life in the villages and in increasing employment opportunities in rural areas"(Final report, Addis Abeba conference, 15-25 may 1961).At the level of Cameroon, the adaptation discussion took the form of ruralization because it was argued that the country was largely rural. Addressing the population at a Congress in Garoua in 1970, the Head of state emphasized on the need for the ruralization of education, whereby education will be adapted at all levels, to real social and economic needs in Cameroon. He also stated that "as the economy of the country is essentially rural-based on agriculture and forestry, with even the incipient industrialization being based on the processing of the produce of the land, the reform has been called ruralization of education.

The crisis in Education in Cameroon necessitated an innovation in the education system. According to Lallez (1974), the problem of Primary education has existed for some time in both the western and the eastern region of Cameroon. The ENIR and IPAR were designed as essential means of solving the problem. The first criticism was that primary education was very expensive. Very few pupils completed their primary education and even smaller proportion obtained the primary school certificate. There was a high rate school dropout and large number of repetition. Consequently, only very small numbers of school leavers including those who completed the course and obtained a diploma were able to easily integrate and take an active part in society. Lallez (1974) argued that the intolerable paradox of the education system was therefore that, while being very costly and training only elite, it did not train the elite properly to achieve personal fulfilment or to play their due role in national development.

In west Cameroon in 1960/1961, 159,000 pupils were counted in the first grade of primary school. Six years later there were only 54, 000 registered in the final grade with a wastage rate of approximately $66 \%$ and only $31.8 \%$ of the pupils in the final primary grade obtained the first school leaving certificate. Lallez (1974) contended that long before 1967, it was generally accepted that the main reason for the poor performance of the education system was the insufficient training of the vast majority of primary school teachers. He argued that if children are being poorly educated, the cause must first be sought in the educators themselves. The poor standard of primary education was firstly not only due to the low level of the qualification of teachers, but also to the unsuitability or incorrect orientation of the education given which may be unsuited not only to the pupils receiving it, to their circumstances, their way of life and their outlook, but also the social and economic needs of their country which supports them and to whose life and development they must in turn make a contribution. Teachers therefore were not properly qualified to give the kind of education needed. By inadequate qualification, Lallez meant inadequate knowledge. The training itself, its methods, contents, and above all its objectives were being questioned. This therefore called for a redefinition of objectives, radical changes in methods, attitudes and curricula.

Two fundamental objectives of the ruralization were firstly, to enable the school " not to concern itself solely with producing bureaucrats and technocrats for whom outlets are steadily dwindling but also to draw young people's attention to many employment opportunities open to them in the primary and secondary sectors. Secondly, it was to orient the primary school pupils towards entrance into secondary school and the ruralized school should at the same time prepare the best pupils to integrate into working life, using the same curricula and methods in both town and country. The rural primary school was supposed to be 'centre of influence in the community' which it would become first of all through the education given to its pupils.

\section{Content of RuRalization}

Lallez (1974) intimated that Cameroon has made ruralization the cornerstone of her postindependence primary school reform. The ruralization of education objective stressed the acquisition 
From Adaptation to Ruralization: A historical Analysis of Curriculum Policy Implementation in Cameroon Schools from the Colonial to Post Colonial Period

of two kinds of knowledge: Such include instrumental knowledge that involved the teaching of conventional school subjects to serve as "instrument for the study of different aspect of life and environmental knowledge that comprised of strategies related to the improvement of the community". The conference of Education in Africa (1961) suggested that efforts should be made to bring the school to the countryside physically and in terms of a programme more in line with rural needs and interests. In an attempt to adapt education programme to rural conditions considerations should be given to experiments in rural school curricula combined with rural community programmes.

The policy of ruralization stipulated that the curriculum of schools should be geared towards the needs of Cameroonians. There was the need for the educational system within Cameroon to satisfy the fervent desire of the people for the expansion of education of quality. This should be reoriented to the economic and development need of individual areas. The policy of ruralization stressed the need of education at all levels to be directed by all means to their own culture. As Cameroonian students exposed to the scientific and cultural aspects of outside world, they need to be thoroughly grounded in a firm knowledge of their own cultural heritage. This could be achieved by adapting educational curricula, particularly at the primary and lower secondary level, to rural and village life. This would be a rurally-oriented school since Cameroon is predominantly a rural country. According to Tambo (2003) the ruralized school would concern itself among other things with the dissemination of knowledge and techniques needed in improving its quality in the rural communities. Efforts should be made to bring the school to countryside physically and in terms of a programme more in line with rural needs and interest.

The policy of ruralization was seen as an important factor in raising the productivity of the agricultural economy in enriching the community life in the village and in increasing employment opportunities in rural areas. It will help diminish the number of school leavers who flock to the towns and cities for employment. The curriculum according to ruralization policy should be designed to ensure that the children acquire skills; attitude, knowledge and predisposition that would enable them contribute positively in the task of rural development (Tambo, 2000).

The policy stipulated that the curriculum of the schools, particularly those in the rural areas, should be geared to the development needs of the rural areas. To this end therefore the objective of the curriculum of the rural school centred on the acquisition of three principal abilities. Namely: The ability to think and to express oneself, the ability to act and the ability to learn. The rationale for the acquisition of such abilities was hinged on the fact that the adults in the modern societies must be capable of thinking logically and expressing themselves; of taking initiatives and acting; of continuing to learn in order to adapt themselves to change; and to retrain for another occupation if necessary. This acquisition of abilities must however go hand in hand with the acquisition of instrumental knowledge which comprises mainly of providing the children with the instruments that will enable them exercise and develop the three principal abilities.

Consequently, the primary school continue to teach the standard subjects like mathematics, English, French, which must however be rooted in the setting of Cameroonian life and culture. The acquisition of such knowledge occupies a pivotal position between the training designed to develop the basic abilities and that which will permit the acquisition of a second type of knowledge that will help pupils to know their environment well with the aim of transforming it. For this purpose, the traditional compartmentalization of subjects taught will be replaced by interdisciplinary disciplines. This can be explained by the fact that the more the fields of study are separated, the greater the risk that each of them will split up, and the greater the risk of moving towards a deductive, teacher centred form of education placing a good deal of emphasis on theoretical and abstract knowledge, which amounts to cutting teachers off from their pupils and the school from its environment. The study of the environment through interdisciplinary subjects will provide children with knowledge directed towards practical applications. The new school will therefore rid itself from 'those encyclopaedic pretensions which transformed pupil into a memory and dissociated culture of life' (Lallez, 1974). Instead, the pupils will acquire a certain item of knowledge and apply them to practical situations. This way, the school thereby naturally finds its place again within the village.

\subsection{Implementation of the Policy of Ruralization}

The implementation of Ruralization as a Post-colonial Curriculum started in 1967, when the government of Cameroon realized that primary education in the country, particularly in East 
From Adaptation to Ruralization: A historical Analysis of Curriculum Policy Implementation in Cameroon Schools from the Colonial to Post Colonial Period

Cameroon, was not adapted to the realities of the new nation. As an attempt at solving these problems, the Head of State in April 1967, created the 'Institute de Pedagogic Applique a Vocation RuraleIPAR' Yaounde to reform education in the French-speaking Provinces so that it would meet the needs of Cameroon, which was predominantly $80 \%$ of the population being involved in Agricultural activities and still live in rural areas. IPAR was to train teachers to give children the sort of education which will make it possible for them to have a better life after the school course.

Considering that the educational problems of English-speaking Cameroon were similar to those of the French-speaking Cameroon in most respects, the Head of state in 1974 promulgated the setting up of IPAR-Buea, 'Institute for the Reform of Primary education' (Report on the Reform of Primary Education, Buea-April 1977). Addressing the population at the IPAR graduation ceremony in Yaounde in June 1970, the Head of State stated that;

The school of today, particularly in Africa, should not concern itself with producing bureaucrats and technocrats for whom outlets are still steadily $d$ windling. It should draw young pupils' attention to the many opportunities open to them in the primary and secondary sectors. This is why at the Garoua Congress I put special emphasis on the need for the ruralization of education.

He further stated that:

The ruralized school should at one and the same time enable the best pupil to pursue their study while the remaining bulk of the pupils will have to be integrated into working life, using the same curricula and methods in both town and country.

As a follow up to the above, a Presidential Order No.277/CAB/PR of $10^{\text {th }}$ October, 1974, created four sections at IPAR Buea. They included:

- Environmental Studies, (Agricultural and Social Aspects)

- English Language

- Mathematics

- Village Technology (Intermediate Technology).

The creation of IPAR-Buea was a joint undertaking between the Cameroon and the UNDP/UNESCO. They provided both financial and human resources to set up the programme. Bilateral aid was also received from the G.T.Z. and the British Council. Experts from the bi-lateral agencies worked in close co-operation with a team of Cameroonians to carry out the research and to compile reports.

The work in the reform of primary education to be carried out by IPAR Buea was to be done in two Phases was based on the activities carried out by the four units of I.P.A.R. Buea. These units included Mathematics, Arts and Craft Technology, English Language, and environmental Studies.

Phase one of the tasks was to undertake an extensive research on community needs and expectations in order to make recommendation to the Government as to the nature and the form of the Reform of Primary Education. The report that was written and sent to the government in June 1977 was titled 'Report on the reform of primary education' was based on research

The central theme of the report stated that Education should take note of differences in pupils' abilities, their different environment, social and economic background. It also stated that the educational system should be flexible enough for students to be giving individual guidance. In order to accomplish these goals, a new kind of education must have a new structure based on the concept of community development. Therefore education should;

- Meet economic and social needs

- Promote equity, equality and justice

- Provide more open access to crucial selection processes

- Provide opportunity for further learning and

- Provide the necessary facilities for effective education. 
From Adaptation to Ruralization: A historical Analysis of Curriculum Policy Implementation in Cameroon Schools from the Colonial to Post Colonial Period

They argued that if education provides needs 'then the citizenry should be intelligent and industrious, healthy and happy, good natured and upright...' (Report on Reform of Primary Education 1977. p.8). The report based its finding on data that was systematically collected, analyzed and interpreted from the education system of Cameroon to provide a basis for recommendation to government regarding educational reform at primary school level in Cameroon.

The study which was carried out in schools and communities of the North West and South West Region, as well as the Western Region was aimed at preparing pupils during their primary school years in such a way that they become integrated in their communities as useful and productive members. The research procedure to be followed by the four units was outlined as follows;

- To recognize and define the problems

- To form hypotheses relating to the problems

- To gather data to lest the hypotheses

- To carry out the analysis of data gained through appropriate work

- To make recommendations based upon the findings

- To suggest ways of implementing the recommendations with regard to the reform of primary education. The results obtained from the research to the government were discussed as follows;

\subsection{The Environmental Studies Report}

The research team of the environmental studies unit was composed of Dr. Bermann, H, an Expert in Environmental studies specifically in Agricultural Aspects from Germany, Mr. Bude, U. also an Expert in Environmental studies but specialized in social aspect from Germany, Divine V. J. who was acting director of IPAR, and also a counterpart with specialty in Agricultural Aspect and Mr. Ashuntantang G.T another countered specialized social studies.

The report made by the unit based on a survey carried out in 79 communities and primary school from both English-speaking provinces, stated amongst other things, that education should aim at socializing the individual by providing the knowledge and techniques to become aware of one's environment and of the problems and changes taking place within it and if possible act within the environment to improve conditions. The report emphasized the environmental variations within English-speaking Cameroon. It mapped out the differences according to the following three criteria,

- Access of communities/schools to government and non-government services,

- Ethnic composition

- Land use Systems.

They argued that since the children will have to face the different environment, it was the task of IPAR to spell out what kind knowledge, skills and attitude the children should develop during the course of Environmental studies.

In the report, the environmental unit reviewed the state of school farm work and proposed measures of improvement to make it an integral part of Environmental studies. They stated the need expressed by rural communities and outlined a plan by which senior primary schools could orientate part of their teaching programme towards meeting such needs. They proposed the following strategies:

- Setting up Education Resource Centres for teachers which fully reflect the needs of a particular local environment.

- Improved supervisors and guidance of teachers by peripatetic rural science experts

- Reforming the examination system

- Changes in the practice of training and posting teachers

- Bringing community members with skills to offer into the school

The report also urged that the local culture and traditions be integrated into the school curriculum while acknowledging the difficulties involved, The final recommendation had that in order to make the reform of primary education and in particular the teaching of Environmental studies a viable proportion, some expenditure on equipment, materials and improved school building was essential. 
From Adaptation to Ruralization: A historical Analysis of Curriculum Policy Implementation in Cameroon Schools from the Colonial to Post Colonial Period

\subsection{Art and Craft/Technology Report}

The team was composed of Mr. Short, R. and expert in Arts and crafts village Technology from British Council in U.K, Mr. Gwankobe R.N. a counterpart in village Technology and Miss Nsong R.N. also in village Technology both from Cameroon. This unit expressed concerned that the existing primary school curriculum was not sufficiently work oriented thus, students/pupils leaving school did not possess the necessary basic skills and attitude which would enable them to find a place in and make a productive contribution to either the rural or urban economy.

A survey carried out on state of Arts and craft in school indicated that, attempts at including manual activities in the school curriculum "has been greatly unsuccessful" (Report on the Reform of Primary Education, 1977. p.14). They identified the problem as resulting from inappropriate training and equipment, poor objectives, shortage of materials, insufficient integration with and support by the community, inadequate administrative support and follow-up. They stated in the report that, the major contribution to the past failure to develop and sustain a meaningful programme of activities is the attitude of teachers themselves were still generally committed to the "ideals of a classical education embracing the Greek ideas of practical and experimental knowledge and of manual work as interior to mental". The unit aimed at:

1) Developing a programme of craft activities relevant to the needs of the individual and his community.

2) Developing a more positive attitude towards craft education and its implication in terms of economic development on the part of the teacher and

3) To investigate the possibility of establishing small-scale village industries for school leavers.

The unit also carried out an extensive and detailed survey in the North and South West Provinces in 1975 to find out which crafts were practiced in both provinces. They also identified the craftsmen and women their sources of materials and how their products were marketed. Based on their findings,, experimental work in the development of village technology was instituted. Feasibility trails of selected crafts were introduced in some schools.

Recommendations made in the report suggested that the teaching of domestic arts, traditional and contemporary craft and technology be included in the school curriculum to be studied for not less than 120 minutes weekly and should be compulsory for both boys and girls.

They also recommended that every senior primary class should have a specialist capable of teaching all aspects of the subject. These specialist teachers should be supported by local craftsmen and other persons willing to offer the advice and assistance to the school.

They emphasized the need for initial financial and material support to establish the new programme and also to provide in-service training to some selected teachers.

\subsection{Mathematics Report}

The unit also carried out their report in the two English-speaking provinces. This report was based on investigations involving primary school teachers, teacher trainers, pre-school and primary school children, school syllabuses and results of the 1970 First School Leaving Certificate Examination. The team examined the existing state of Mathematics education at the time and made proposal for revision of the syllabus. Their ultimate objective was to propose a syllabus in which the "Cameroonian children will acquire a sound mathematics background through the problem solving approach will aid them to be useful and productive citizens whether they continue school or seek employment in the rural or the urban sector".

The findings indicated that the mathematics programme did not contain consistent objectives and direction, the content of the syllabuses in both provinces were varied and lacked a core structure. The programme did not meet the needs nor reflected the background experiences of the children and there was no guide and directions to teachers in terms of guide books and training in mathematics methodology.

Recommendations made were centred on the formation of a uniform primary syllabus, a programme for pre-service and in-service teachers training; for a continuing research and trial testing of the 
From Adaptation to Ruralization: A historical Analysis of Curriculum Policy Implementation in Cameroon Schools from the Colonial to Post Colonial Period

proposed syllabus and for continuing research on children in order to create a pupil's profile. This unit submitted a proposal for a mathematic syllabus.

\subsection{English Language Report}

The term was made up and not exclusively of Jone, B.I.O, and expert in English language and Textbook production, Greenland, J. Teacher Training and curriculum Development both from Britain and Mr. Kajih, J.T, a counterpart in English language Section.

They expressed concern that the current Evan Primary English course by J.C Gagg used as text books in primary school was inadequate in terms of quality and of quantity. They also argued that the English language course consisted of many supplementary booklets which were rarely purchased by parents due to cost.

The research carried out by the team was aimed at improving on the existing course by incorporating cultural data from the environment so as to have a relevant and meaningful language course as well as provide adequate content with appropriate vocabulary and structures.

Schools and communities were visited in the language areas chosen and questionnaire was given in writing and orally to children and adult respondents. Class 7 pupils in English-speaking provinces were used as respondents while CoursMoyenDeux pupils were used in the French-speaking western province. Native speaking adults and other local resource persons were used to explain orally in the mother tongue the task demanded of the children community chiefs PTA members of cultural groups in the area where the selected schools were located.

Materials collected from the field were processed for subsequent use as language materials children's competences in English were tested before experiment exercise were introduced to the experimental schools. Seventy exercises were designed and worked through with pupils in class seven of the five experimental schools. Materials collected in French in the West province were translated into English for use in experimental exercises. Draft copies of CAMPEM I and II were written though they were never completed.

The team recommended that continued research be carried out in Phase II while they still continue with feasibility trials, codification of exercises and content writing.

\section{Phase II}

The data collected in Phase I by the different sections were supposed to be used to produce educational materials, write textbooks and training materials for the new school. National syllabuses were drawn and submitted to the government in the Report on the Reform of Primary Education for approval. Teaching guides were also prepared for years 1 to 4 and tried out in pilot schools and teacher training colleges. This was in preparation for the start of Phase II. It is interesting to note that till date this phase never took off. While waiting for the start of Phase II, the institute continued to carry out field surveys, conduct experiments, drafts and try out teaching guides, organize seminars and radio talks to disseminate and sensitize teachers and the general public about the work of the Institute.Though the government never provided feedback on the recommendations made by the four sections of IPAR in the Report of Primary School Reform of April 1977, IPAR continued with its activities in preparation for the start of Phase II, such that by 1989, many achievements had been made:

The English language section began and completed the selection of the vocabulary and structural content of the CAMPEM III. Other major accomplishments included the writing and launching of the Resource Handbook for the teaching of English in Cameroon schools,

The Village Technology Section prepared teaching guide for schools. They helped in the design and construction of the sign board and poultry farm building at Mile 17 Experimental Farm.

The mathematics unit wrote the integrated Mathematics Pupils Book Two, Revised Pupils Book one, and drafted Chapters one to fifteen of the Mathematics Pupils Book Three. The section also carried out field trials on the books to test the suitability of the exercises, and to get the reactions of the teachers who used the materials during the experimentation.

In the Environmental Studies Unit, lessons on Rural Science and Agriculture were given by members of the section to classes 5-7 pupils of some four pilot schools of G.S Molyko, G.S. Muea, C.S. Muea 
From Adaptation to Ruralization: A historical Analysis of Curriculum Policy Implementation in Cameroon Schools from the Colonial to Post Colonial Period

and CBC Bolifamba on Mondays, Tuesdays and Wednesdays of each school week. Visits were made to some 15 Primary Schools in the North West Province. Loan Schemes were provided to schools. Teachers' guides were prepared on Rural Science, Agriculture, Observational Sciences, Civics, History and Geography for class three and four.These recommendations have not been fully implemented in the Cameroonian educational system. Standfield (2008) contends that, unfortunately, things haven't exactly gone to plan and almost half a century later, exactly the same problems are still being discussed. The Cameroon Government however made attempts at pursuing the policy of ruralization especially at the primary school level.

\subsection{Inhibitive Factors Accounting Non Implementation of Ruralization}

In spite of the strategies and resources used at the preparatory phase of the policy, its implementation never really kicked off. National syllabuses that were drawn to be used in the new school have till date not been approved by government and have never been used. IPAR Buea and Yaounde have been turned into research centres and since the directors retired no replacement have been made till date.

\subsection{Resistance}

One reason that accounts for resistance in the implementation of the policy was the ambiguity of the term ruralization. According to Lallez (1974), a large section of public opinion saw the reform as retrograde rather than progressive and innovative. This was due to the frequent and deliberate use of the word ruralization, a term which evoked association with the historical past and with colonialism in which context ruralization meant the opposite of industrialization, urbanization, modernization and development. The new education would make Cameroon an agricultural country and would moreover make any attempt at industrialization impossible.

Another issue raised was the fact that if the new primary education was to be rural, then it was obviously preparing a way, either intentionally or inadvertently for a split between the village school and the town school and thus promote discrimination between two kinds of children; country children and town children. Ruralization was therefore resisted because of the societal stratification it perpetuated. Paulo Freire (1972) called this 'the pedagogy of the oppressed' and what Ivan Illich (1971) described as 'the institutionalization of values' in which he claims leads to social polarization and psychological impotence particularly in the areas of class, race and gender.

Another reason for the failure of the policy was that the role the school was called upon to play in rural development was unrealistic. The arguments put up were that if the main concern of the schools were to prepare the vast majority of children who do not continue their studies beyond primary level to take an active part in the rural society, from which they come, should some thought not be to the education of the children who would go to secondary education? This therefore represent a trend towards the establishment of two kinds of primary school, one of which, on the basis of discrimination takes in children who intend to go to secondary school, while the other is reserved for children who are destined or condemned to spend their lives on the land. The above claim goes a long way to support the fact that when people are not clear about the meaning of change, they always try to resist it.

\section{LACK OF EXPERTISE}

Akoulouze (1984) is of the opinion that the change approach initiated for the reform of primary education in Cameroon was comprehensive and revolutionary from the outset because it intended to reorganize the whole school system once. However while suggesting a comprehensive change of the primary education system, the reform did not carry out an inventory of the needs of the public in the domain of primary education. No study was carried out to conduct an inventory of the needs of the society. Furthermore, though the first Phase of the reform in Primary education was based on empirical data systematically collected, analysed and interpreted to provide recommendations to governments, this procedure never reached the second phase.

Jacob Ndifon explained in an interview that one reason why the second phase never took off was because after the British and German governments withdrew their technical experts who would have designed the materials needed for the new school, the Cameroonian officials who were left to work on the reform project were not competent in textbook writing and did not possess the expertise in carrying out the strategies needed for the change. The local course writers produced very low quality 
From Adaptation to Ruralization: A historical Analysis of Curriculum Policy Implementation in Cameroon Schools from the Colonial to Post Colonial Period

form of materials. There was an absence of manpower and government support. This corroborates Dodge (2000) who points out that in the beginning stages of implementation, it is helpful to have someone who is knowledgeable with the curriculum to introduce it to the entire staff. This may involve bringing in a specialist or conducting an in-house training if the resources to do so are available. Providing several days of orientation to pre-service training at the beginning in a new programme year ensures that everyone has a shared vision, understands the philosophy and approach, and knows how to apply it to every day decision making. Without this implementation effort may be futile.

Another failure in the implementation of Ruralization was in the area of teacher training. IPAR was supposed to train teachers in Nursery and Primary to use the new materials that would have been produced in the second Phase of the project. This never happened mainly because the time that IPAR was advocating for teacher training, teacher training was suspended in the Cameroon education system. This was a clear indication of government lack of support to the project. However, the institute provided in-service training for its entire staff and in addition sent some abroad for training in research, evaluation, professional and academic up-dating with assistance from foreign Governments through the approval of the Cameroon government. These efforts were however not sufficient enough to provide required number and quality of teachers for the new programme.

\section{Political CONCERNS}

Another reason for the failure of the reforms was resistance from inspectors and top officials of the Ministry of National Education. Introducing the reforms meant a loss of a certain number of advantages initially enjoyed by the bosses.

Before the initiation of the reforms, the Inspectors of education were publishing textbooks and as such were benefitting from the authors' rights. With the reforms, the organizational chart of IPAR envisaged a production unit of textbooks through research carried out within the institution. This was going to wipe out the popularity and material gains of the inspectors. Furthermore, it was planned that IPAR was going to train a staff that will offer refresher courses to the teachers in service. Before the reforms, the training of teachers and organization of refresher courses to teachers (pedagogic conferences) were in the hands of the inspectors. Moreover, the reforms ushered in methods and strategies that were unknown to the inspectors. This therefore meant that the role of inspectors would be jeopardized.

Lastly, according to the organizational chart of the IPAR, the place of the inspectors in the implementation of the reform would be insignificant. Lallez (1974) held that the inspectors resisted the change to an extent that they resorted to sabotage. He reported that at a national commission made up of inspectors who met in 1967 and 1968 to prepare the school programme, instead of reducing and changing the traditional programmes, the commission rather lengthened them and even went as far as adding aspects that were in absolute contradiction to the spirit of reform (Lallez, 1974. P.40). This is in support of Mcneil's (1977) view that those who develop curriculum at the national level, also have problems, among which is how to get the curriculum adopted. He contends that there are difficulties in clearing the political hurdles of textbooks committees, curriculum commissions, boards of education and other groups so that the curriculum is made available to teachers. An even bigger problem is how to get their product actually used as intended in schools.

Fullan and Park (1982), contended that most often than not, teachers are left to themselves to grapple with their everyday matters. The situation becomes more complicated when a curricula change is proposed. Teachers begin to ask whether the change will benefit them and students and what will it cause them in terms of time and energy if the change must be implemented. They usually choose not to change when the answers to these questions are not positive. Fullan (2007.p.89) further added that clarity about goals and means is a perennial problem in the change process. Even when there is agreement that some kind of change is needed, as when teachers want to improve some area of the curriculum or improve the school as a whole, the adopted change may not be at all clear about what the teachers should do differently. He stated that lack of clarity diffuses goals, and unspecified means of implementation represent a major problem at the implementation stage of any curriculum making attempt. Teachers and others find that the change is simply not very clear as to what it means in practice. 
From Adaptation to Ruralization: A historical Analysis of Curriculum Policy Implementation in Cameroon Schools from the Colonial to Post Colonial Period

\section{CONCLUSION}

Generally speaking, IPAR has made considerable efforts in the implementation of the policy of ruralization in the Cameroon educational system. However these efforts have not been put to use because the recommendations made for the reform of education and sent to government for approval and use were ignored. Though proposals made by IPAR for the reform of education were not put to immediate use, the report influenced the organization of the 1995 Education Forum and the subsequent formulation of the 1998 Education Law that acts as a guide for teaching and learning in Cameroon schools.

\section{RECOMMENDATIONS}

The idea of ruralization was a laudable one because it preached education that will be relevant to the needs of the society. However, this policy failed at the implementation level because of the ambiguity of the term ruralization and the unrealistic role that the school was called upon to play.

Although the use of the term 'ruralization created disagreement and contention within the educational community, the basic idea of ruralization, as a policy, was to ensure that education was adapted to needs of learners and their respective societies.

Today, that idea lives in the objectives of relevant and inclusive education. From this perspective, this study recommends that:

The concept of ruralization be transformed to that of relevant education, with the insistence that Cameroon school curriculum continues to be developed to meet the needs of learners and their different communities within the national territory.

This means that for issues of relevance to be addressed effectively, the curriculum will seize to be centralized at each point so that at the regional, divisional and sub-divisional levels, schools should adapt the curriculum to their environment as they find it. There must therefore be decentralization of curriculum to permit different environment to adapt the programmes to their environment. For example if we have to teach economic activities in geography or economics, schools in Limbe will focus more on fishing while those in the north on cattle rearing.

Above all government should create a mechanism to keep monitoring, and overseeing the work on curriculum implementation. Supervision of schools should be seen as a healthy relationship to help teacher build their skills and motivate them.

\section{REFERENCES}

[1] Aka, A. (2002). British Southern Cameroons 1922-1961: Studies in colonialism and underdevelopment. Plateville, MD: Nkemnji Global Tech.

[2] AKoulouze, R. (1984). La reforme de l'Enseignment primaire au Cameroun, 1967-1984.Yaounde: Mimeograph Yaounde IPAR

[3] Cameroon, MINEDUB(2010). Statistiques des resultats des examens. Yaoundé, Cameroon.

[4] Cameroon, MINEDUC (1995) National forum on education, 1995. Yaounde: MINEDUC

[5] Cameroon, MINEFI. (2000). Annuaire Statistique du Cameroun. Direction de la Statistique et de la Comptabilité Nationale (DSCN). Cameroon Census Bureau.

[6] Cameroon, Presidency (1966). Law No. 96-06 of 18 January 1996 to amend the Constitution of 2 June 1972. Official gazette of the Republic of Cameroon. Yaounde: Presidency.

[7] Cameroon, Presidency (1972). The Constitution. Official gazette of the republic of Cameroon. Yaounde: Presidency.

[8] Fullan, M. \&Pomfret, A. (1977). Research on curriculum and instruction implementation. Review of Educational Research.

[9] Fullan, M. \&Stiegelbauer, S. (1991). The new meaning of educational change. London: Cassell

[10] Fullan, M. (1982). The Meaning of Educational Change. New York: Teachers College Press.

[11] Fullan, M. (2007). The new meaning of educational change. $4^{\text {th }}$ ed. New York: Teachers College Press.

[12] Fullan, M. and Park P. (1981). Curriculum implementation. Ontario. Queen's Park

[13] Fullan, M.(1994). Implementation of innovations. In T. Husen, T.N. Postlethwaite (Eds.), The International Encyclopaedia of Education (pp.239- 284). Pergamon, Oxford. 
From Adaptation to Ruralization: A historical Analysis of Curriculum Policy Implementation in Cameroon Schools from the Colonial to Post Colonial Period

[14] Fullan, M., Bennett, B., \&Rolheiser-Bennett, C. (1990). Linking classroom and school improvement. Educational Leadership, 47(8), 13-19.

[15] Fullan, M. and Park, P. (1981). Curriculum Implementation. Toronto: Ministry of Education.

[16] Good, C.V. (1959). Introduction to educational research. New York: Appleton-Century-Crofts, Inc.

[17] Gwanfogbe, M.B.(2006). Changing regimes and educational development in Cameroon. Bamenda: Unique Printers

[18] Ihims, J.A. (2003). A Century of western education in Cameroon: A study of its history and administration (1844-1961). Bamenda: Unique Printers

[19] Kaba, B.D and Rayapen, L.C.A. (1990). Relevant education for Africa. Yaounde: PWPA Book.

[20] Lallez, R. (1974). An experiment in the ruralization of Education. IPAR and the Cameroonian Reform. Experiments and Innovation in Education. No. 8. UNESCO Policy

[21] Moumouni, A. (1968). Education in Africa. London: Trinity press.

[22] Ndille, R. (2015). From adaptation to ruralisation in Cameroon education policy; 1922-2002: Replacing six with half a dozen. African Educational Research Journal.Vol.3(3), pp.153-160

[23] Shu, S. N. (1982). Education in Cameroon. In A. B. Fanfunwa and J. Aisiki (Eds), Education in Africa: A comparative Survey. Pp.28-48. London George Allen and Urwin

[24] Shu, S.N. (1985). Landmarks in Cameroon education. Nooremac Press

[25] Tambo, L. (2000). Strategic concerns in curriculum development in Cameroon. In: T. Ndongko and L. Tambo, (Eds), Educational development in Cameroon 1961-1999. Platville, MD: Nkemnji Global Tech

[26] Tambo, L.( 2003). Cameroon national education policy since the 1995 forum.Limbe: Design House

[27] UNESCO (1953). UNESCO's mimeographed report on the use of mother-tongues in education.

[28] UNESCO (1994). The Role of Africa Student Movement in the Politic and Social Evolution of Africa from 1900-1975. UNESCO

[29] UNESCO, (1995). Report on the state of Education in Africa: Education strategies for the 1990s: Orientation and Achievement. UNESCO.

[30] West Cameroon Ministry of Education and Social welfare.(1963). West Cameroon education policy: Investment in education. Buea:

[31] West Cameroon Govt. Press. Kennedy, M. (1996). Self-determination and trust: My experiences and thoughts. In D. J. Sands \& M. L.Wehmeyer (Eds.), Self-determination across the lifespan: Independence and choice for people with disabilities (pp.35-47). Baltimore: Paul H. Brookes

Citation: Yaro Loveline. "From Adaptation to Ruralization: A historical Analysis of Curriculum Policy Implementation in Cameroon Schools from the Colonial to Post Colonial Period". International Journal of Humanities Social Sciences and Education (IJHSSE), vol. 6, no.8, 2019, pp. 63-77. doi: http://dx.doi.org/10.20431/2349-0381.0608007

Copyright: (C) 2019 Authors. This is an open-access article distributed under the terms of the Creative Commons Attribution License, which permits unrestricted use, distribution, and reproduction in any medium, provided the original author and source are credited. 